\title{
THE DISTRIBUTION OF SALMONELLA AGGLUTININS IN SERA OF HEALTHY ADULTS AT IBADAN
}

\author{
BY PATRICK COLLARD, RANJIT SEN, \\ Department of Bacteriology, University College, Ibadan \\ AND DAVID MONTEFIORE \\ University College Hospital, Ibadan, Nigeria
}

(With 2 Figures in the Text)

\section{INTRODUCTION}

There have been a number of previous surveys of Salmonella agglutinins in normal sera in various parts of the world (Smith, MacVie \& Newbold, 1930; Gardner \& Stubington, 1932; Giglioli, 1933; Lewin, 1934; Alves, 1936; Pasricha, Panja \& Lal, 1936; Beattie \& Elliot, 1937; Gregory \& Atkinson, 1938; Tabet, 1940; El-Hakeem, 1940; Schwabacher, Ross \& Carruthers, 1943; Hughes, 1955). All these surveys were limited to the incidence of a few agglutinins only, usually those against Salmonella typhi $\mathrm{H}, \mathrm{O}$ and $\mathrm{Vi}$ and the somatic and flagellar suspensions of one or more of the paratyphoid organisms.

The results reported in this communication present a survey of the agglutinin titres against seven somatic and sixteen flagellar suspensions among the adult population of Ibadan, Nigeria.

Ibadan is an African city in the rain-forest belt of Western Nigeria (latitude $7^{\circ} 26^{\prime} \mathrm{N}$. and longitude $3^{\circ} 54^{\prime} \mathrm{E}$.) with a population of $500,000-700,000$. The sanitary services are primitive, consisting mainly of night-soil collection, and even this is not universally operative. There is piped water in the town, but the majority of the population draw their drinking water from shallow wells or streams.

During the years 1956 and 1957, 2117 normal sera were examined for the presence of salmonella agglutinins, 1054 from male blood donors and 1063 from women attending the Antenatal Clinic of the University College Hospital, Ibadan. No sera were accepted from persons known to be suffering from gastro-enteritis or an enteric type of fever, but no attempt was made to exclude those people who had received T.A.B. inoculation, as anti-typhoid inoculation is rarely undertaken amongst the local population. The survey was started in an attempt to define what constituted an abnormal Widal reaction in the population amongst whom we are practising in Ibadan. We were further interested to see whether the agglutinins present in the normal population were related to the antigens of salmonella strains isolated during the period 1956-57. The results reported indicate a base line for the 'normal' agglutinin titres found in the population in Ibadan. 


\section{MATERIALS AND METHODS}

\section{Agglutinin survey}

Each serum was tested at a dilution of 120 against seven somatic and sixteen flagellar suspensions as follows:

Pure ' $O$ ' suspensions of Salmonella sp.

\begin{tabular}{ll} 
Salm. paratyphi $A$ & Salm. london \\
Salm. paratyphi $B$ & Salm. aberdeen \\
Salm. paratyphi $C$ & Salm. poona \\
Salm. typhi & \\
\multicolumn{1}{c}{ Phase I 'H' suspensions of Salmonella sp. } \\
Salm. paratyphi $A$ & Salm. menston \\
Salm. paratyphi $B$ & Salm. typhimurium \\
Salm. paratyphi $C$ & Salm. thompson \\
Salm. typhi & Salm. oranienburg \\
Salm. newport & Salm. london \\
Salm. derby & Salm. bovis morbificans \\
Salm. enteritidis & Salm. bareilly \\
Salm. dublin & Salm. poona
\end{tabular}

If agglutination occurred at $1 / 20$ dilution, the end-point of the agglutinin titre was determined.

All the suspensions were supplied by the Standards Laboratory, Colindale, London, with the exception of the Salm. oranienburg flagellar suspension and the Salm. poona flagellar suspension, which were prepared in our laboratory.

Both somatic and flagellar agglutinations were performed in round-bottomed tubes, using $0.5 \mathrm{ml}$. diluted serum and $0.5 \mathrm{ml}$. of the suspensions.

Somatic agglutination tests were placed in a $37^{\circ} \mathrm{C}$. water-bath for $4 \mathrm{hr}$., then kept in a refrigerator at $4^{\circ} \mathrm{C}$. for $18 \mathrm{hr}$, and read at room temperature on the bench as soon as the condensation on the tubes had evaporated, which usually took $15-30 \mathrm{~min}$.

Flagellar agglutination tests were placed in a $37^{\circ} \mathrm{C}$. water-bath for $2 \mathrm{hr}$., taken out and read after standing on the bench at room temperature for $30 \mathrm{~min}$.

\section{Isolation of salmonella strains}

Materials examined for the presence of Salmonellae included faeces, blood, pus, urine, gall bladder from operation and spleen obtained from post-mortem. The majority of the specimens were obtained from patients with gastro-enteritis, pyrexia or osteitis attending the University College Hospital. Faeces from food handlers, other healthy persons and patients being investigated for conditions other than gastro-enteritis or pyrexias were also examined to determine the presence of salmonella carriers.

The method of isolation and identification of salmonellae in this laboratory has previously been reported (Collard \& Sen, 1956). 


\section{RESULTS}

\section{Agglutinins}

The absolute numbers and percentages of sera agglutinating with various suspensions, at titres of $1 / 20,1 / 40,1 / 80,1 / 160$, are shown for the males in Table 1 and for the females in Table 2.

Table 1. Number examined: 1054 sera from normal males

\begin{tabular}{|c|c|c|c|c|c|c|c|c|c|}
\hline \multirow[b]{3}{*}{ Salmonellae } & \multirow[b]{3}{*}{ Antigen } & \multicolumn{8}{|c|}{ Dilutions } \\
\hline & & \multicolumn{2}{|c|}{$1 / 20$} & \multicolumn{2}{|c|}{$1 / 40$} & \multicolumn{2}{|c|}{$1 / 80$} & \multicolumn{2}{|c|}{$1 / 160$} \\
\hline & & No. & $\%$ & No. & $\%$ & No. & $\%$ & No. & $\%$ \\
\hline \multicolumn{10}{|l|}{ ' $O$ ' Somatic } \\
\hline Salm. paratyphi $A$ & $1,2,12$ & 27 & $2 \cdot 6$ & 10 & 0.95 & 3 & 0.29 & 2 & $0 \cdot 19$ \\
\hline Salm. paratyphi B & $1,4,5,12$ & 144 & $13 \cdot 9$ & 55 & $5 \cdot 3$ & 10 & 0.95 & 2 & $0 \cdot 19$ \\
\hline Salm. paratyphi $C$ & 6,7 & 35 & $3 \cdot 3$ & 14 & $1 \cdot 3$ & 5 & 0.48 & 1 & 0.095 \\
\hline Salm. typhi & 9,12 & 227 & $21 \cdot 6$ & 119 & $11 \cdot 3$ & 24 & $2 \cdot 25$ & 3 & 0.29 \\
\hline Salm. london & 3,10 & 660 & $63 \cdot 0$ & 490 & $46 \cdot 5$ & 205 & $19 \cdot 6$ & 44 & $4 \cdot 15$ \\
\hline Salm. aberdeen & 11 & 281 & $26 \cdot 7$ & 177 & $16 \cdot 7$ & 58 & $5 \cdot 5$ & 7 & 0.65 \\
\hline Salm. poona & 13,22 & 93 & $8 \cdot 85$ & 44 & $4 \cdot 2$ & 17 & $1 \cdot 62$ & 5 & 0.48 \\
\hline \multicolumn{10}{|l|}{ 'H' Flagella } \\
\hline Salm. paratyphi A & $\mathbf{a}$ & 17 & $1 \cdot 62$ & 9 & $0 \cdot 86$ & $\mathbf{5}$ & 0.48 & 1 & 0.095 \\
\hline Salm. paratyphi $B$ & $\mathbf{b}$ & 15 & $1 \cdot 43$ & 11 & $1 \cdot 05$ & 4 & $0 \cdot 38$ & 2 & $0 \cdot 19$ \\
\hline Salm. paratyphi $C$ & $\mathrm{c}$ & 7 & 0.65 & 6 & $0 \cdot 57$ & 2 & $0 \cdot 19$ & 2 & $0 \cdot 19$ \\
\hline Salm. typhi & $d$ & 54 & $5 \cdot 15$ & 24 & $2 \cdot 25$ & 14 & $1 \cdot 3$ & 6 & 0.57 \\
\hline Salm. newport & e.h. & 2 & $0 \cdot 19$ & 1 & 0.095 & $\longrightarrow$ & - & $一$ & - \\
\hline Salm. derby & f.g. & 5 & $0 \cdot 48$ & 2 & $0 \cdot 19$ & 2 & $0 \cdot 19$ & 1 & 0.095 \\
\hline Salm. enteritidis & g.m. & 22 & $2 \cdot 1$ & 14 & $1 \cdot 3$ & 4 & $0 \cdot 38$ & 1 & 0.095 \\
\hline Salm. dublin & g.p. & 12 & $1 \cdot 15$ & 7 & 0.65 & 2 & $0 \cdot 19$ & - & $\ldots$ \\
\hline Salm. menston & g.s.t. & 22 & $2 \cdot 1$ & 10 & 0.95 & 1 & 0.095 & - & - \\
\hline Salm. typhimurium & i & 42 & $4 \cdot 0$ & 18 & 1.72 & 5 & 0.48 & 1 & $0 \cdot 095$ \\
\hline Salm. thompson & $\mathbf{k}$ & 183 & $17 \cdot 5$ & 130 & $12 \cdot 4$ & 57 & $5 \cdot 42$ & 21 & 1.95 \\
\hline Salm. oranienburg & m.t. & 19 & $1 \cdot 81$ & 10 & 0.95 & 4 & 0.38 & 3 & $0 \cdot 29$ \\
\hline Salm. london & l.v. & 20 & 1.9 & 11 & $1 \cdot 05$ & 4 & $0 \cdot 38$ & 1 & 0.095 \\
\hline Salm. bovis morbificans & $\mathbf{r}$ & 14 & $1 \cdot 3$ & 5 & $0 \cdot 48$ & - & - & - & - \\
\hline Salm. bareilly & $\mathrm{y}$ & 10 & 0.95 & 7 & $0 \cdot 65$ & 3 & 0.29 & 1 & 0.095 \\
\hline Salm. poona & $\mathbf{z}$ & 31 & $2 \cdot 95$ & 24 & $2 \cdot 25$ & 10 & 0.95 & 3 & 0.29 \\
\hline
\end{tabular}

The most striking findings are the large number of sera from both sexes agglutinating the Salm. London ' $O$ ' suspension $(3,10)(63 \%$ at $1 / 20$ and $4 \%$ at $1 / 160)$ and the Salm. thompson ' $H$ ' suspension (k) (approximately 20\% at $1 / 20$ and $2 \%$ at $1 / 160$ ) and the large number of suspensions that many sera agglutinate at titres of $1 / 20$.

The higher proportion of men than women showing agglutination of Salm.typhi ' $O$ ' suspension $(9,12)$ at titres of $1 / 20$ and $1 / 40$, might suggest that some of the men had received T.A.B. inoculation while in the army, but on examination the figures for Salm. paratyphi $A$ and $B$ do not support this explanation, as they show no significant difference between the sexes. 
Table 2. Number examined: 1063 sera from normal females

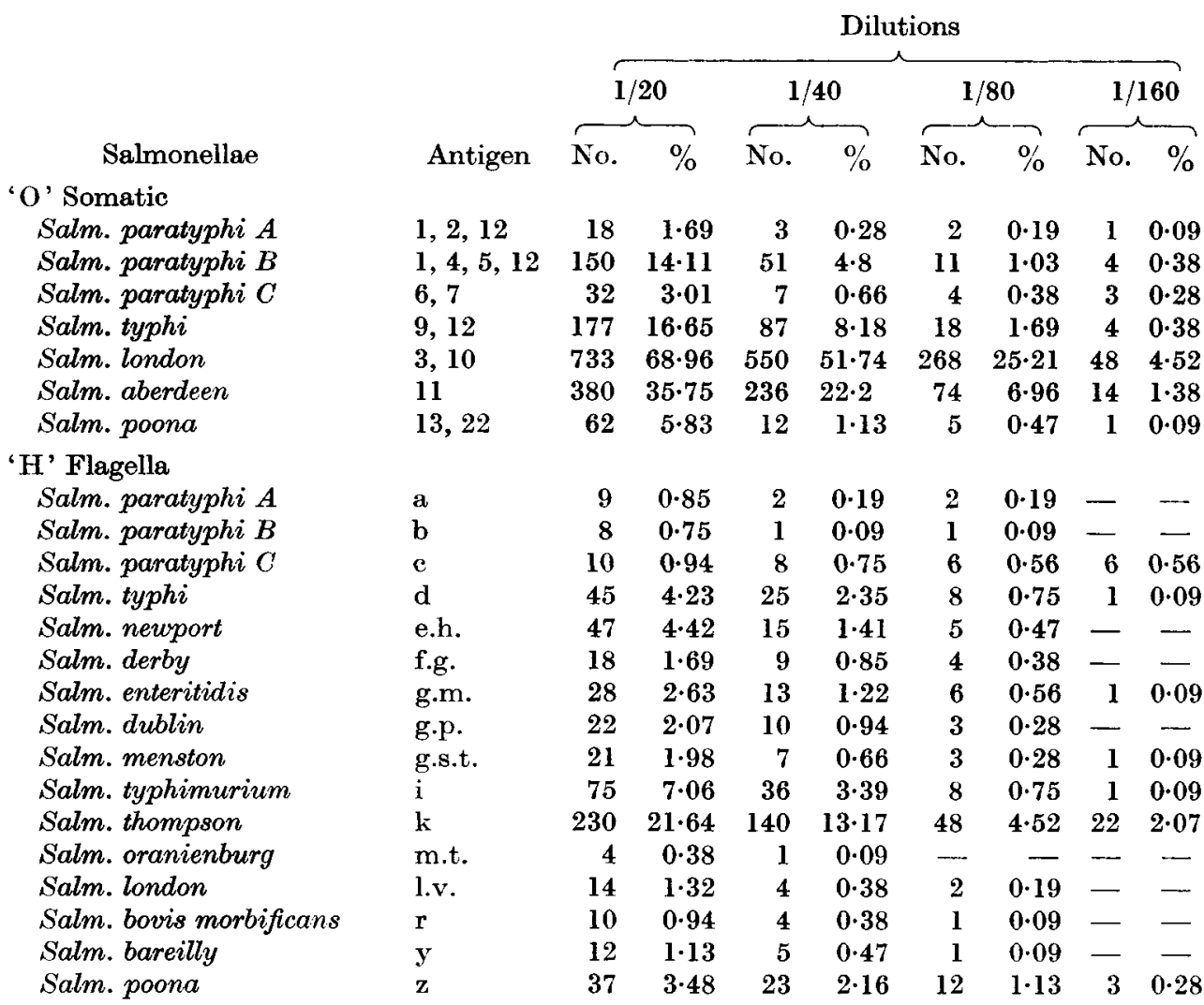

\section{Salmonella strains isolated}

256 strains comprising of 78 different species of salmonellae were isolated in 1956 and 1957 from the population in Ibadan and are shown in Table 3. This table, comprising only the strains from, as far as we know, the resident population in Ibadan, shows the diversity of the serotypes to be found here. The complete list of salmonellae isolated during this period is reported elsewhere (Collard \& Sen, $1958 a, b, 1959)$.

\section{DISCUSSION}

The general picture of a population where normal sera contain agglutinins, against a large number of antigens in the salmonella group, fits in well with the cultural results obtained in our laboratory. It is reasonable to expect that the number of different antibodies in the sera will parallel the diversity of the antigens found in the organisms infecting the population, and this can be seen to be so in this case.

The relation between the frequency with which an agglutinin occurs at a titre of $1 / 20$ in the sera examined, and the frequency with which the corresponding antigen occurred in 256 strains of salmonellae isolated from man during 1956 and 1957, are shown in Figs. 1 and 2.

It can be seen that there is a rough correlation between the incidence of the antigens and of the antibodies, with certain striking exceptions. The small 
proportion of strains containing the somatic antigens of the Kauffmann-White Schema, O-groups E and F, and the flagellar antigen (k) is out of all proportion to the high percentage of sera which show antibodies against these antigens.

These antibodies which occur in a much greater number of sera than would be expected from the antigenic pattern of the indigenous salmonellae may be natural antibodies unrelated to antigenic stimulation, or they may arise as a result of

Table 3. Salmonella isolated from the population in Ibadan during 1956 and 1957, which comprises healthy carriers and patients with clinical disease

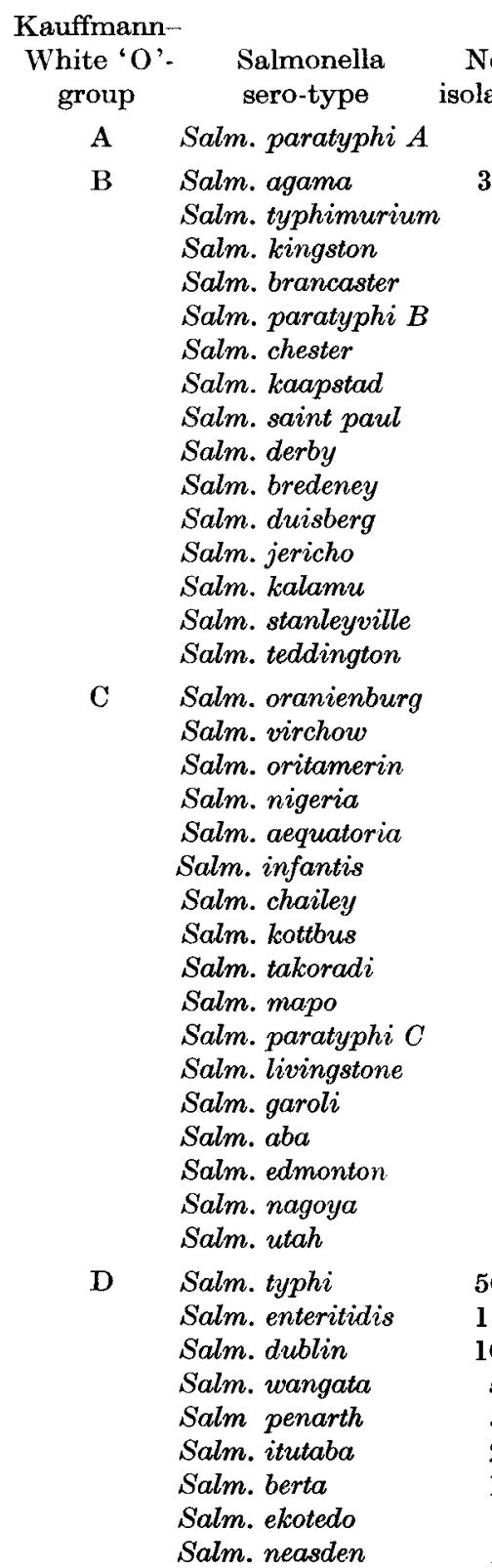

\section{Kauffmann- White 'O'- group}
Salmonella sero-type

E Salm. senftenberg

Salm. give

Salm. adabraka

Salm. elizabethville

Salm. oxford

Salm. weybridge

Salm. butantan

Salm. mokola

Salm. onireke

Salm. shangani

F

Salm. rubislaw

G Salm. durham

Salm. poona

Salm. cubana

Salm. ajiobo

Salm. ibadan

Salm. tel-el-kebir

Salm. agbeni

Salm. worcester

H Salm. albuquerque

I Salm. amunigun

Salm. adeoyo

Salm. brazil

Salm. salford

Salm. patience

Salm. taunton

Salm. ank

Salm. chicago

Salm. urbana
No. of isolations 3 1 1 1 1 1 1 1 7 3 3 2 1 1 1 1 1 1 2 1 1 1

monschaui Salm. agodi 1

Salm. sp. [New type 40: $\mathrm{z}_{29}$ ] 1

Salm. waycross 2

Salm. berkeley 1

Salm. bere 1

Salm. luke 1 


\section{2}

\section{Patrick Collard, Ranjit Sen and David Montefiore}

infection with organisms other than salmonellae which contain the antigenic component in question. The antigenic component 11 is known to be possessed by a number of strains of Escherichia coli and by certain other members of the family Enterobacteriaceae (Wheeler, Stuart, Rustigian \& Borman, 1943; Kauffmann, 1954), also Salmonella group $\mathrm{E}$ is known to have serological relationships with Escherichia freundii (Edwards, McWhorter, McCurdy \& Davis, 1954; Harada,

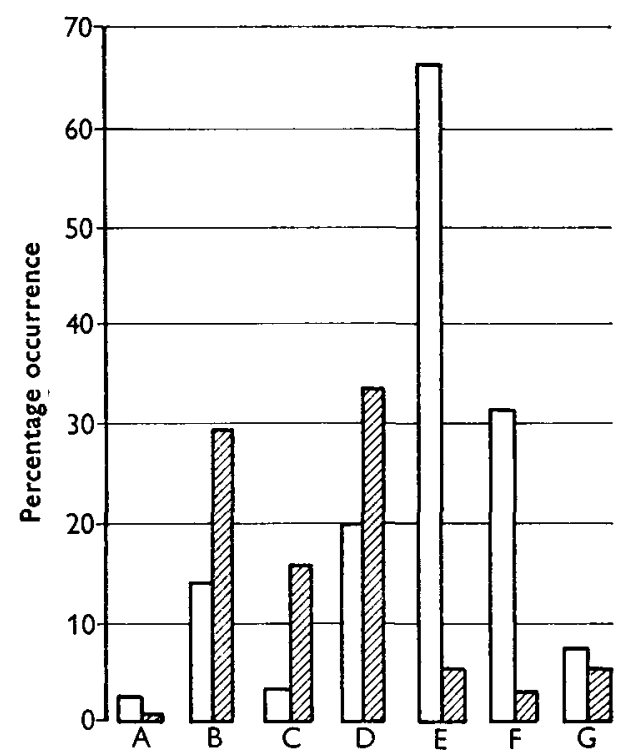

Fig. 1. Somatic antigens and antibodies. Antigens in 256 strains from human sources; $\square$, antibodies in normal sera at $1 / 20$ dilution. $\delta, 1054 ;$ \&, 1063.

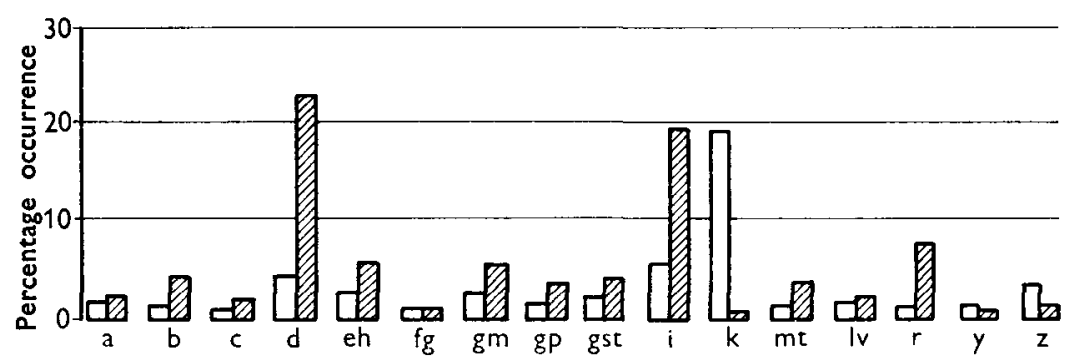

Fig. 2. Flagellar antigens and antibodies. Antigens in 256 strains from human sources; $\square$, antibodies in normal sera at $1 / 20$ dilution. $\delta, 1054 ; \circ, 1063$.

Matsuyama \& Yamamoto, 1956); further, the sera of the few newly arrived Europeans we have been able to examine did not contain agglutinins against Salm. london, while sera from a small number of Europeans who have lived in this country for more than 2 years did show a proportion of individuals with agglutinins against the Salm. london ' $O$ ' suspension at titres of $1 / 40$ and 1/80.

The difference between the male and the female sera with respect to agglutinins against the flagellar antigen of Salm. newport (e.h.) are significant at $P<0.01$. This difference suggests that in this case we may be dealing with a natural antibody, and that the gene controlling its appearance might be sex linked. 
While the biological significance of the aberrant antibodies, those against the somatic antigens 3,10 and 11 and the flagellar antigens $k$ and e.h., remains obscure, the clinical significance of the distribution of such antibodies in the normal sera is clear. For practical purposes we regard any titre that occurs in more than $5 \%$ of the normal population-that is, one that might be found by chance in $1 / 20$ normal sera - as not being a significant indication of active infection. This arbitrary rule has the advantage of giving statistical significance at $P<0.05$ to any 'positive' results.

Table 4. ' $O$ ' agglutinations: $\%$ of sera agglutinating at $1 / 20$

\begin{tabular}{|c|c|c|c|c|c|c|c|c|}
\hline & Ibadan & Ghana & $\begin{array}{c}\text { Br. } \\
\text { Guiana }\end{array}$ & Egypt & India & Watford & $\begin{array}{l}\text { Cam- } \\
\text { bridge }\end{array}$ & $\begin{array}{l}\text { Oxford } \\
\text { and } \\
\text { Edinburgh* }\end{array}$ \\
\hline Salm. typhi & $21 \cdot 6$ & $5 \cdot 0$ & $16 \cdot 3$ & $6 \cdot 7$ & $11 \cdot 8$ & $2 \cdot 0$ & $9 \cdot 0$ & $26 \cdot 0$ \\
\hline Salm. paratyphi A & $2 \cdot 6$ & - & - & - & $2 \cdot 1$ & - & - & - \\
\hline Salm. paratyphi B & $13 \cdot 9$ & $11 \cdot 5$ & $20 \cdot 3$ & - & $5 \cdot 0$ & $7 \cdot 0 \dagger$ & $22 \cdot 0 \dagger$ & $22 \cdot 0 \dagger$ \\
\hline Salm. paratyphi $C$ & $3 \cdot 3$ & - & $19 \cdot 4$ & - & - & - & - & - \\
\hline
\end{tabular}

* These were comparable groups in two surveys in Oxford and Edinburgh respectively and the results have been combined.

$\uparrow$ Suspension employed was prepared from Salm. typhimurium.

Table 5. ' $H$ ' agglutinations: $\%$ of sera agglutinating at $1 / 20$

$\begin{array}{lcccccc} & \text { Ibadan } & \text { Ghana } & \text { Guiana } & \text { Egypt } & \text { India } & \text { Manchester } \\ \text { Salm. typhi } & 5 \cdot 2 & 15 \cdot 0 & \mathbf{2 4 \cdot 6} & \mathbf{7 \cdot 9} & \mathbf{2 8 \cdot 2} & \mathbf{4} \cdot 7 \\ \text { Salm. paratyphi A } & \mathbf{1 . 6} & \mathbf{2 \cdot 5} & \mathbf{9 \cdot 4} & \mathbf{3 \cdot 9} & \mathbf{7 \cdot 1} & - \\ \text { Salm. paratyphi } B & 1 \cdot 4 & \mathbf{3 . 5} & \mathbf{6 \cdot 0} & \mathbf{5 \cdot 5} & \mathbf{1 1 \cdot 4} & \mathbf{2 \cdot 0} \\ \text { Salm. paratyphi } C & 0 \cdot 7 & \mathbf{1 . 5} & \mathbf{1 4 \cdot 3} & \mathbf{3 \cdot 8} & - & 0 \cdot 6\end{array}$

We have compared the frequency of significant typhoid and paratyphoid agglutinins found in the populations we studied with the results of similar surveys reported from Ghana (Hughes, 1955), British Guiana (Giglioli, 1933), Egypt (Tabet, 1940), India (Pasricha et al. 1936), Oxford (Gardner \& Stubington, 1932), Manchester (Smith et al. 1930), Edinburgh (Beattie \& Elliot, 1937) and Watford and Cambridge (Schwabacher et al. 1943). Tables 4 and 5 show the percentages of sera in each of these surveys which agglutinated certain suspensions at or above a titre of $1 / 20$. The striking point about these tables is the variability shown between the different series in tropical countries, even when the two countries are as close as Nigeria and Ghana. While it would be unwise to overlook the effect of differences in technique that have occurred over the years, it remains probable that such differences do reflect a different epidemiological pattern or genetic make-up of the populations, and further serological surveys using an extended battery of suspensions would be of great interest.

\section{SUMMARY}

The distribution of salmonella agglutinins among 2117 normal sera from 1054 male and 1063 female adult population of Ibadan is described, and the relation of the distribution of the agglutinins with the antigens of salmonella strains isolated over a 2-year period in a hospital in Ibadan, Nigeria, is discussed. 


\section{Patrick Collard, Ranjit Sen and David Montefiore}

We wish to thank Prof. B. G. T. Elmes and Dr J. B. Lawson for their help wit the collection of specimens. Our thanks are due to Mr R. J. Leeming, F.I.M.L.T for his technical assistance.

(Part of the material upon which this paper is based is included in a thesis fo submission for the Cambridge M.D. degree by one of us (D.M.).)

\section{REFERENCES}

Alves, W. D. (1936). 'O' agglutinins for $B$. typhosum in an uninoculated native populatio S. Afr. med. J. 10, 6.

Beatime, C. P. \& Elliot, J. S. (1937). Serological diagnosis of enteric in the inoculate J. Hyg., Camb., 37, 36.

Collard, P. \& SEN, R. (1956). Isolation of Salmonellae from cattle in Ibadan. W. Afr. med. . $5,118$.

Collard, P. \& Sen, R. (1958a). Salmonella types isolated in Ibadan, Nigeria. Trans. : Soc. trop. Med. Hyg. 52, 283.

CollARD, P.\& SEN, R. (1958b). Salmonellae isolated from man in Ibadan. W. Afr. med. J. 7, 9

Collard, P. \& SEN, R. (1959). Salmonellae isolated at Ibadan. Second Report: strai isolated during 1957. W. Afr. med. J. (in the Press).

Edwards, P. R., McWhorter, A. C., McCurdy, J. \& Davis, R. (1954). A culture Escherichia freundii serologically related to the genus Salmonella. J. Bact. 68, 756.

EL-HAKEEM, A. Z. (1940). An investigation into the natural agglutinins of the Egyptias in relation to the Widal reaction. Lab. Med. Progr. Cairo, 1, 21.

Gardner, A. D. \& Stubington, E. F. (1932). Granular ' $O$ ' agglutination in paratypho $\mathrm{B}$ and typhoid fevers. J. Hyg., Camb., 32, 516.

Gigliour, G. (1933). Agglutinins for typhoid-paratyphoid group in a random sample population of British Guiana. J. Hyg., Camb., 33, 379.

Gregory, T. S. \& Atkinson, N. (1938). An investigation of the normal agglutinins for typho: and paratyphoid bacilli in human sera in Victoria, and the interpretation of the Wid test. J. Hyg., Camb., 38, 566.

Harada, K., Matsuyama, T. \& Yamamoto, A. (1956). Detection of Escherichia freuna which completely possesses somatic antigen of Salmonella $\mathbf{E}$ group and direction variation of the isolated bacteria. Gunma J. Med. Sci., Maebashi, 5, 218. (Abstr. Bull. Hyg. (1957), 32, 370.)

HugHes, M. H. (1955). Enteric fevers and normal Salmonella agglutinins in the Gold Coak J. Hyg., Camb., 53, 368.

KaUfFmanN, F. (1954). Enterobacteriaceae, 2nd ed. p. 339 et seq. Copenhagen: Ejn: Munksgaard.

LEwIN, W. (1934). ' $\mathrm{H}$ ' and ' $\mathrm{O}$ ' agglutination of $B$. typhosus in a group of suspected typho cases and in a group of unselected individuals. S. Afr. med. J. 8, 731 .

Pasricha, C. L., Panja, G. \& Lal, S. (1936). Immunological methods in the determinatic of infection in a random sample of hospital admissions. Indian med. Gaz, 71, 245.

Schwabacher, H., Ross, M. \& CaRruthers, H. L. (1943). Agglutination titres of norm sera. Lancet, i, 739.

Sмiтh, M. M., MACVIE, M. H. \& Newbold, E. M. (1930). An investigation into the agglu1 nating power of human sera for Bacillus typhosus and various allied organisms. $J$. Hy! Camb., 30, 55.

TABET, F. (1940). The value of Widal reaction in Egypt. Lab. Med. Prog., Cairo, 1, 13.

Wheeler, K. M., Stuart, C. A., Rustigian, R. \& Borman, E. K. (1943). Salmonel antigens of coliform bacteria. J. Immunol. 47, 59.

(MS. received for publication 10. VII. 59) 